\title{
Milk yield and composition of crossbred Sahelian $\times$ Anglo-Nubian goats in the semi-intensive system in Mali during the preweaning period
}

\author{
Souleymane Sanogo • Mohamed Momani Shaker • \\ Hamidou Nantoumé • Abdel-Fattah Z. M. Salem
}

Accepted: 3 July 2012 / Published online: 13 July 2012

(C) Springer Science+Business Media B.V. 2012

\begin{abstract}
The aim of this study was to evaluate milk yield and its composition during the preweaning period for Sahelian goats (SG) and Anglo-Nubian (AN) crossbred depending on some factors. The experiments were conducted from January to December 2008 for 44 suckled and hand-milked does, randomized, and divided into two equal groups: SG $(n=22)$ and $\mathrm{F}_{1}$ Anglo-Nubian $\times$ Sahelian goats $(1 / 2 \mathrm{AN} ; n=$ 22). The does and their offsprings were kept in a pen where they stayed indoors for 45 days before they were allowed outdoors when the weather was suitable. Each category received supplemental feeds depending on the season (rainy season, dry cold season, and dry hot season). The average daily milk yield was recorded weekly from parturition to 100 days of age. Individual milk samples were taken for chemical analysis in connection with the yield measurements twice per month from the fourth week of lactation throughout the different seasons (rainy, cold dry, and hot dry). The daily milk yield differed between breed types ( $P=$ 0.001 ) during the preweaning, while the effect of kids' sex on daily milk production was not significant. Litter size affected milk yield up to day $60(P=0.032)$ where does with
\end{abstract}

S. Sanogo $\cdot$ M. M. Shaker $(\bowtie)$

Institute of Tropics and Subtropics, Czech University of Life

Sciences,

Kamýcká 129, Suchdol,

16521 Prague 6, Czech Republic

e-mail: Momani@its.czu.cz

H. Nantoumé

Laboratoire de Nutrition Animale, Institut d'Economie Rurale (IER),

CRRA de Sotuba,

BP 262, Bamako, Mali

\section{A.-F. Z. M. Salem}

Department of Animal Production, Faculty of Agriculture, Alexandria University,

Alexandria, Egypt twins producing more milk than those with single kid. However, at day 100 , both groups had similar $(P=0.001)$ milk production. Total milk yield at weaning increased by $103 \%$ in $1 / 2 \mathrm{AN}$ over SG. The highest concentration of total solids of milk was (12.76\%) recorded in the hot dry season. The results of this study indicate that crossbreeding native Sahelian goats with high potential Anglo-Nubian buck improved milk production and its composition.

Keywords Anglo-Nubian · Crossbreed · Milk yield · Milk composition $\cdot$ Sahelian goats
Abbreviations
SG Sahelian goats
$1 / 2 \mathrm{AN} \quad \mathrm{F}_{1}$ of $\mathrm{AN} \times$ Sahelian goats
RS Rainy season
DCS Dry cool season
DHS Dry hot season
DNPIA Direction Nationale des Productions et Industries Animales
DNS Direction Nationale des Statistiques
DNA Direction Nationale de l'Agriculture

\section{Introduction}

Livestock production constitutes the main source of income for more than $30 \%$ of the population of Mali and represents the principal source of animal protein supply for its population. It contributes up to $10 \%$ in gross domestic product in the country (DNPIA 2008). Goats are bred in extensive pastoral (nomadic grazing) and agropastoral system (sedentary grazing) in Mali. The stock is estimated at 13.1 million goats (DNPIA 2008). They provide mostly meat and produce milk all year round with a low yield (Sangaré and 
Pandey 2000). Their milk is usually insufficient and rarely sold. In spite of this important stock, small ruminant husbandry has several constraints that are related to health, feeding, management, and genetics. Those factors call for a decreasing of milk yield which is estimated to be $627 \mathrm{~g}$ day $^{-1}$ with $4 \%$ fat during the first 12 weeks of lactation and 108 gday $^{-1}$ at 26 weeks (Sangaré and Pandey 2000). Theoretically, milk consumption per capita was estimated to 10 301 per year in Mali (Bonfoh 2005), and about $60 \%$ of the dairy products consumed were imported (DNS 1999).

An improvement in the goat milk yield and composition of the local breeds can be made through improved management and crossbreeding with higher yielding local or exotic goats (Zahraddeen et al. 2007). Moreover, the milk production potential of local Sahelian goats in the semiarid zone can be improved through selective breeding or crossbreeding them with exotic Anglo-Nubian breed (Sanogo et al. 2010). A crossbreeding program is currently underway in Mali to improve milk production of native Sahelian goats by siring them with imported Anglo-Nubian bucks. The present study deals with some factors influencing milk production and chemical contents of native Sahelian does and their crossbred with AngloNubian goats in the $F_{1}$ generation, which proved as a success in this improvement program.

\section{Materials and methods}

This research was carried out in the Regional Center of Agronomic Research at Samé in the region of Kayes, located between $14^{\circ} 29^{\prime} \mathrm{N}$ and $11^{\circ} 34^{\prime} \mathrm{W}$. The average rainfall varies from 550 to $900 \mathrm{~mm} \mathrm{year}^{-1}$ (DNA 2007). The vegetation consists of thorny plants and shrubs. The average daily maximum temperature in the city is $35^{\circ} \mathrm{C}$, with temperatures usually peaking in April and May at an average of $46{ }^{\circ} \mathrm{C}$. The seasonal characteristics of the area are rainy season (June-September), dry cold season (October-January), and dry hot season (February-May).

\section{Animals and management system}

This study was conducted on a herd of native Sahelian goats, crossbred with two Anglo-Nubian bucks, imported from England in 2004. It was in the framework of a cooperative research initiative between the Czech University of Life Sciences, Prague, Institute of Tropics and Subtropics (CULS Prague), and Institute of Rural Economy, Mali. Forty-four does were randomly located in two groups as follows: 22 Sahelian goats (SG) and $22 \mathrm{~F}_{1}$ of $\mathrm{AN} \times$ Sahelian goats $(1 / 2 \mathrm{AN})$ does. Calibrated beakers for milk measurement, feeders, and watering tanks were provided. Two cement shelters were built with large boxes for the does and a small one for the kids. Each box had a solid floor and an open yard of $10 \times 6 \mathrm{~m}$.

All the goats were kept in a semi-intensive system, grazing natural pasture from 9:00 to 11:00 a.m. and from 3:00 to $6: 00$ p.m. Besides rangeland grazing, the animals received additional feeds as supplements depending on the season, the age (animal category), and the physiological state of the animal. They received supplemental feeds as shown in Table 1 as determined by Nantoumé et al. (2011). Aliment Bétail Huicoma is a concentrate mixture of $2 / 3$ cottonseed hulls and $1 / 3$ cottonseed meal. The bush hay is natural that includes mainly a grameneous species Shonefeldia gracilis that is collected and stored for use during the dry season. This supplementation program takes into account the scarcity and the lower nutritive value of feed resources as related to the animal productions during the different seasons. Therefore, the effect of the season on milk production was no longer an issue because of the supplementation depending on the season that would have biased that effect.

\section{Data collection}

Data were collected from January to December 2008 for two types of breeds ( $\mathrm{SG}$ and $1 / 2 \mathrm{AN}$ ). The first evaluation of milk yield was done after 7 days after parturition, and then, weekly measurements were done after separating kids from the dams at night and then during the daytime along 100 days (at 30, 60, and 100 days) of lactation. The does were hand-milked twice a day (evening and following morning) for milk yield evaluation. Kids were double weighed before (P1) and after suckling ( $\mathrm{P} 2)$. The difference in weight $\mathrm{P} 2-\mathrm{P} 1$ gave the amount of milk consumed per kid, and then, the residual milk was milked and measured. The total of these two quantities of milk gave the production of milk in

Table 1 Quantities of feed supplements given per animal category (in grams per animal per day) depending on the age and the season

\begin{tabular}{|c|c|c|c|}
\hline Categories & $\begin{array}{l}\text { Rainy } \\
\text { season }\end{array}$ & $\begin{array}{l}\text { Cold } \\
\text { dry season }\end{array}$ & $\begin{array}{l}\text { Hot } \\
\text { dry season }\end{array}$ \\
\hline Young & 0 & $\begin{array}{l}100 \mathrm{~g} \text { of aliment } \\
\text { bétail } \\
\text { Huicoma } \\
\left(\mathrm{ABH}^{\mathrm{a}}\right)\end{array}$ & $\begin{array}{l}100 \mathrm{~g} \text { of bush hay } \\
+100 \mathrm{~g} \text { of } \mathrm{ABH}^{\mathrm{a}}\end{array}$ \\
\hline Adulte & 0 & $\begin{array}{l}200 \mathrm{~g} \text { of } \\
\mathrm{ABH}^{\mathrm{a}}\end{array}$ & $\begin{array}{l}200 \mathrm{~g} \text { of bush hay } \\
+200 \mathrm{~g} \text { of } \mathrm{ABH}^{\mathrm{a}}\end{array}$ \\
\hline $\begin{array}{l}\text { Lactating } \\
\text { female }\end{array}$ & $\begin{array}{l}200 \mathrm{~g} \text { of } \\
\text { cottonseed } \\
\text { meal }\end{array}$ & $\begin{array}{l}400 \mathrm{~g} \text { of } \\
\text { cottonseed } \\
\text { meal }\end{array}$ & $\begin{array}{l}200 \mathrm{~g} \text { of bush hay }+ \\
400 \mathrm{~g} \text { cottonseed } \\
\text { meal }\end{array}$ \\
\hline
\end{tabular}

${ }^{a}$ Mixture of $1 / 3$ of cottonseed meal and $2 / 3$ cottonseed hulls 
the afternoon. The same method was used to evaluate milk production of the following morning. The daily milk production was monitored by adding these two partial yields (Nantoumé et al. 2005). The result of the first control was multiplied by the number of days between the birth and the first control. The results of two consecutive measurements (controls) were added and divided by two and multiplied the daily yield by the interval between two controls. At the end of lactation for each female, the last quantity was multiplied by seven. Milk sampling was carried out throughout the entire lactation period of each does twice per month. After each milking, samples of $30 \mathrm{ml}$ of milk were taken, labeled by the animal number, and analyzed for fat, protein, solids-not-fat, density, and added water contents using the LactiCheck Analyzer (Model LC$01),{ }^{1}$ a compact, portable, and reliable machine.

\section{Statistical analysis}

The statistical analysis was done using the general linear model procedure in SAS software package (SAS 2002) for a completely randomized design, with the variable milk yield at 30,60, and 100 days of lactation. The treatments were analyzed for their significance using one-way analysis of variance. Duncan's multiple range was used to compare the means of daily milk production and its composition of different types of does with a significance level of $P<0.05$. Two statistical models of fixed mains effects were used:

Model I : $\quad Y_{i j k}=\mu+A_{i}+B_{j}+C_{k}+E_{i j k}$

where $Y_{i j k}$ represents the average of the daily milk production at various periods for $i$ th genotype with $j$ th litter size and $k$ th sex of kids; $\mu=$ general mean; $A_{i}=$ effect of the $i$ th genotype ( $i=\mathrm{SG}$ and $1 / 2 \mathrm{AN}) ; B_{j}=$ effect of $j$ th litter size $(j=$ single and twin), and $C_{k}=$ effect of the $k$ th sex ( $k=$ female and male); $E_{i j k}$ is residual error term $N$. Similar model was used to evaluate the percentage of total solids, butterfat, and protein contents of milk depending on genotype, season of lactation, and litter size with interaction between season $\times$ breed type. It is expressed as follows:

Model II : $Y_{i j k}=\mu+A_{i}+B_{j}+S_{k}+(A \times S)_{i k}+E_{i j k}$

where $Y_{i j k}$ represents the percent of total solids, butterfat, and protein of milk; $\mu, A_{i}, B_{j}$, and $E_{i j k}$ have the same meaning as in model I. $S_{k}=$ the effect of $k$ th season $(k=$ rainy, dry cool, and dry hot seasons), and $(A \times S)_{i k}=$ the interaction between genotype and season of lactation.

\footnotetext{
${ }^{1}$ Page \& Pedersen International, Ltd, 158 West Main Street Hopkinton, MA, 01748, USA.
}

\section{Results}

Milk production

Daily milk yield at various ages of kids and total yield, depending upon particular factors, is presented in Table 2 . Total milk yield at 100 days was 67.41 in SG versus 1371 in $1 / 2 \mathrm{AN}$, while the milk yield in $1 / 2 \mathrm{AN}$ was increased to $103 \%$ above that of SG. Daily milk yields at birth were 0.3 and $0.71(P=0.001)$ for Sahelian goats and $1 / 2 \mathrm{AN}$ does, respectively. This tendency was maintained until 100 days with 0.6 and 0.81 for SG and 1/2AN, respectively. Daily milk production was affected by genotype and litter size at various stages of lactation. Lactation curves of the SG and the crossbred 1/2AN are presented in Fig. 1.

Litter size affected milk yield up to day $60(P=$ 0.032) where does with twins producing more milk than those with single kid. At the end of the experiment (day 100), daily milk yields were similar $(P=0.001)$ and average daily milk yields were 0.5 and 0.61 for does with single kid and those with twins $(P=0.001)$, respectively. Average daily milk yields increased to $36 \%$ for does with twins above those with single until day 60. Sex of kid had no influence either on daily milk yield or on total milk production during the experimental period (Table 2).

\section{Milk composition}

Total solids, butterfat, and protein contents depending on particular factors are presented in Table 3. Total solids and butterfat were increased $(P=0.0014)$ by 12 and $22.6 \%$ respectively, while the litter size was not affected $(P=0.32)$. The season of year affected the composition of milk in total solids $(P=0.012)$, butterfat, and protein contents $(P=0.001)$. The highest value of total solids was recorded in the hot dry season (Table 3 ). There was no significant difference for total solids content between the rainy season and the hot dry season, for butterfat contents between the cold dry season and the rainy season, while the protein content increased in favor of the rainy season. The interaction between the breed type and the rainy season affected $(P=0.001)$ butterfat and protein contents $(P=0.0014)$ that increased with SG in the rainy and the hot dry seasons, while no significant difference was found in butterfat percentage. Significant difference $(P=0.021)$ was found in the overall mean of interaction between breed type and season for total solids. Cold dry season $\times$ breed type affected total solids and butterfat contents, but not the protein content. Hot dry season $\times$ breed had increased the difference between breeds in favor of the crossbred 1/ 2AN (Table 3). 
Table 2 Daily milk yield at various ages of kids and total yield, depending upon particular factors

Mean values within the same column with different superscript letters differ significantly at 0.05 level of probability

$N$ number, $S G$ Sahelian goat, $A N$ Anglo-Nubian, $P$ probability, SEM standard error mean

\begin{tabular}{|c|c|c|c|c|c|c|}
\hline \multirow[t]{2}{*}{ Factor } & \multirow[t]{2}{*}{$N$} & \multicolumn{4}{|c|}{ Daily milk production (liters) } & \multirow[t]{2}{*}{ Total yield (liter) } \\
\hline & & Day 7 & Day 30 & Day 60 & Day 100 & \\
\hline \multicolumn{7}{|c|}{ Genotype } \\
\hline SG & 22 & $0.3^{\mathrm{b}}$ & $0.8^{\mathrm{b}}$ & $0.7^{\mathrm{b}}$ & $0.6^{\mathrm{b}}$ & $67.4^{\mathrm{b}}$ \\
\hline $1 / 2 \mathrm{AN}$ & 22 & $0.7^{\mathrm{a}}$ & $1.9^{\mathrm{a}}$ & $1.7^{\mathrm{a}}$ & $0.8^{\mathrm{a}}$ & $136.6^{\mathrm{a}}$ \\
\hline$P$ & & 0.001 & 0.001 & 0.001 & 0.001 & 0.001 \\
\hline SEM & & 0.05 & 0.06 & 0.06 & 0.08 & 0.06 \\
\hline \multicolumn{7}{|c|}{ Litter size } \\
\hline Single & 40 & $0.5^{\mathrm{b}}$ & $1.4^{\mathrm{b}}$ & $1.2^{\mathrm{b}}$ & $0.7^{\mathrm{a}}$ & $89.4^{\mathrm{b}}$ \\
\hline Twins & 4 & $0.6^{\mathrm{a}}$ & $1.5^{\mathrm{a}}$ & $1.3^{\mathrm{a}}$ & $0.8^{\mathrm{a}}$ & $114.6^{\mathrm{a}}$ \\
\hline$P$ & & 0.001 & 0.001 & 0.032 & 0.053 & 0.003 \\
\hline SEM & & 0.06 & 0.14 & 0.13 & 0.07 & 0.09 \\
\hline \multicolumn{7}{|l|}{ Sex } \\
\hline Female & 23 & 0.5 & 1.4 & 1.2 & 0.7 & 102.6 \\
\hline Male & 21 & 0.5 & 1.3 & 1.2 & 0.7 & 101.4 \\
\hline$P$ & & 0.057 & 0.061 & 0.052 & 0.086 & 0.062 \\
\hline SEM & & 0.04 & 0.09 & 0.03 & 0.02 & 0.05 \\
\hline
\end{tabular}

\section{Discussion}

Milk yield

Our results show that the crossbred animals surpassed the native Sahelian goats in term of daily milk yield from parturition to 100 days of lactation. That is probably due to the hybrid vigor of $\mathrm{F}_{1}$ offspring, an additional improvement by the Anglo-Nubian sire. In the same region of Kayes, the local breed, the Sahelian goats, produced lower yields within shorter lactation periods. The length of the lactation fluctuated from 59 to 76 days and milk productions were 0.351 on average after the kids have suckled and 0.601 as total daily yield (Nantoumé et al. 2005). Most results are within the milk yield range $\left(0.400-1.000\right.$ day $\left.^{-1}\right)$ as stated by Malau-Aduli et al. (2003); Missohou et al. (2005) reported that the average daily milk production was

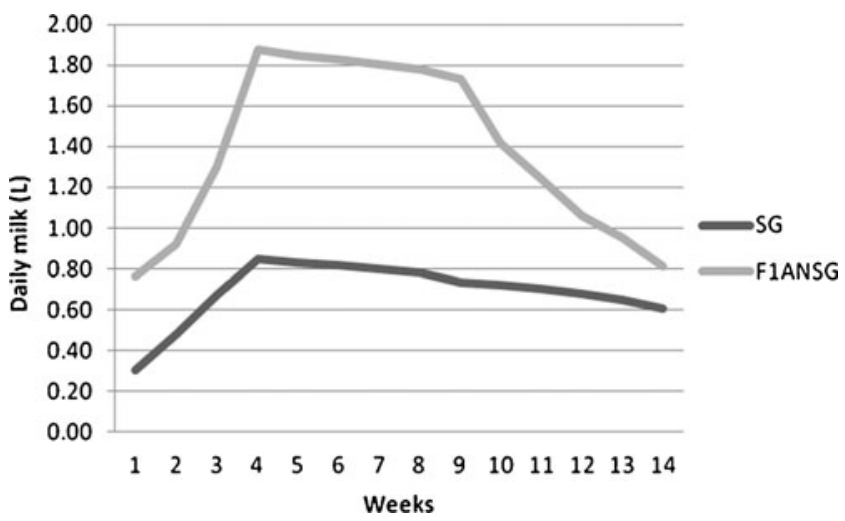

Fig. 1 Lactation curves of the SG and the crossbred F1ANSG
0.541 for the duration of lactation from 3 to 6 months for Sahelian goats in Senegal. The total milk yield was higher than that found by Mumba et al. (2003) for indigenous Malawi goats and for Saanen crossbreeds because of hybrid vigor of crossbred and the proper employed management system to the native Sahelian goats. Our results obtained in this study are in accordance with those reported by Cissé et al. (2002) with higher level reached at week 3 for Sahelian goats in Senegal. Nianogo and Ilboudo (1992) reported an average from 0.47 to 0.7351 between 1 st to 14 th weeks for Sahelian goats, with a peak of production of $1.275 \mathrm{l} /$ head $/$ day $^{-1}$. The values of our study were higher than those reported by Montaldo et al. (1995), for local Mexican goats with high-grade and low-grade Alpine, Saanen, and Toggenburg. Contrary to this, litter size had no significant effect on total milk yield (El-Hassan ElAbid and Abu Nikhaila 2010). Average daily milk yields were greater for does with twins than those with single kid. The report was consistent with that published by Macciotta et al. (2005) and Montaldo et al. (1995), where goats with twins at parturition had higher milk yield than those with single kid. This large milk production of does was probably due to the large size of does bearing twins. In our study, doe with twins' recorded $36 \%$ higher daily milk yield than those with single kid once at day 60. Sangaré and Pandey (2000) found that milk yield was affected by litter size. Milk production was 0.736 day $^{-1}$ for does with twins versus 0.6921 for does with single kid during the first 12 weeks of lactation. Delgado-Pertíñez et al. (2009) in Payoya local dairy goats reported that the sex of 
Table 3 Total solids, butterfat, and protein contents depending on particular factors

\begin{tabular}{|c|c|c|c|}
\hline Factor & Total solids (\%) & Butterfat $(\%)$ & Protein $(\%)$ \\
\hline \multicolumn{4}{|l|}{ Genotype } \\
\hline $\mathrm{SG}(n=22)$ & $11.5^{\mathrm{b}}$ & $4.7^{\mathrm{b}}$ & $3.9^{\mathrm{b}}$ \\
\hline $1 / 2 \mathrm{AN}(n=22)$ & $12.9^{\mathrm{a}}$ & $5.8^{\mathrm{a}}$ & $4.1^{\mathrm{a}}$ \\
\hline$P$ & 0.001 & 0.001 & 0.0014 \\
\hline SEM & 0.21 & 0.12 & 0.03 \\
\hline \multicolumn{4}{|l|}{ Season } \\
\hline Rainy season & $12.4^{\mathrm{a}}$ & $48^{\mathrm{b}}$ & $4.3^{\mathrm{a}}$ \\
\hline Dry cool season & $11.6^{\mathrm{b}}$ & $5.1^{\mathrm{b}}$ & $3.8^{\mathrm{c}}$ \\
\hline Dry hot season & $12.7^{\mathrm{a}}$ & $5.9^{\mathrm{a}}$ & $3.9^{\mathrm{b}}$ \\
\hline$P$ & 0.012 & 0.001 & 0.001 \\
\hline SEM & 0.19 & 0.13 & 0.07 \\
\hline \multicolumn{4}{|l|}{ Litter size } \\
\hline Single & $12.2^{\mathrm{a}}$ & $5.3^{\mathrm{a}}$ & $3.9^{\mathrm{a}}$ \\
\hline Twin & $12.3^{\mathrm{a}}$ & $5.2^{\mathrm{a}}$ & $4.0^{\mathrm{a}}$ \\
\hline$P$ & 0.61 & 0.68 & 0.32 \\
\hline SEM & 0.14 & 0.06 & 0.04 \\
\hline \multicolumn{4}{|c|}{ Interaction season $\times$ genotype } \\
\hline $\mathrm{SG} \times \mathrm{RS}$ & $11.9^{\mathrm{c}}$ & $4.8^{\mathrm{c}}$ & $3.9^{\mathrm{cb}}$ \\
\hline $1 / 2 \mathrm{AN} \times \mathrm{RS}$ & $12.9^{\mathrm{b}}$ & $4.9^{\mathrm{c}}$ & $4.6^{\mathrm{a}}$ \\
\hline $\mathrm{SG} \times \mathrm{DCS}$ & $11.1^{\mathrm{d}}$ & $4.2^{\mathrm{d}}$ & $3.8^{\mathrm{cd}}$ \\
\hline $1 / 2 \mathrm{AN} \times \mathrm{DCS}$ & $12.1^{\mathrm{c}}$ & $5.8^{\mathrm{b}}$ & $3.7^{\mathrm{d}}$ \\
\hline $\mathrm{SG} \times \mathrm{DHS}$ & $11.7^{\mathrm{c}}$ & $5.2^{\mathrm{c}}$ & $3.8^{\mathrm{cd}}$ \\
\hline $1 / 2 \mathrm{AN} \times \mathrm{DHS}$ & $13.7^{\mathrm{a}}$ & $6.7^{\mathrm{a}}$ & $4.0^{\mathrm{b}}$ \\
\hline$P$ & 0.021 & 0.001 & 0.0014 \\
\hline SEM & 0.12 & 0.07 & 0.04 \\
\hline
\end{tabular}

Mean values within the same column with different superscript letters differ significantly at 0.05 level of probability

$S G$ Sahelian goat, $n$ number of animals, $A N$ Anglo-Nubian, $P$ probability, $S E M$ standard error mean, $R S$ rainy season, $D C S$ dry cool season, DHS dry hot season

kids did not result in a significant influence on daily milk production during all period of the trial.

Milk composition

Goat milk composition studied in our experiment showed an increase of concentration of solids-not-fat, butterfat, and protein in the crossbred over the native SG. That was probably due to the hybrid vigor of $F_{1}$ offspring, gained from the high potential of Anglo-Nubian sire. Analogous levels were obtained in improved goats reported elsewhere by Morgan et al. (2003) who reported total solids of $11.6 \%$ in goat milk in France; Berhane and Eik (2006) for Abergelle goats; and Prasad and Sengar (2002) in crossbred Barbari $\times$ Black Bengal. Salem et al. (2004) found that milk of crossbreds Damascus $\times$ Barky had better milk properties than the milk of the pure Barky breed, but lower than that of Damascus goats. Cooper (2001) found that milk composition and quality of crossbred Saanen $x$ indigenous were higher than indigenous goat in Malawi. Total solid percentages were lower than those reported by Malau-Aduli et al. (2003) for the Red Sokoto and Sahelian, respectively, but similar to that found by Kouniba et al. (2007) for Alpine goat in Northern Morocco. Butterfat of Sahelian goats showed higher values than those found by Malau-Aduli et al. (2003) for the Red Sokoto and the Sahelian, respectively, in Nigeria and Mohamed et al. (2007) in Sudanese Nubian. Crossbred $1 / 2 \mathrm{AN}$ had lower butterfat than that reported by Stephen et al. (2004) for the Boer, but within the range of $3.34-5.26 \%$ for Australian rangeland goats and for local goat of Morocco (Kouniba et al. 2007).

Protein content of Sahelian goats was similar to that reported by Carnicella et al. (2008) in Maltese goats in Italy. That of $1 / 2 \mathrm{AN}$ was comparable to the value of $4.16 \%$ found by Berhane and Eik (2006) for Abergelle goats, while Mioč et al. (2008) mentioned that the content of protein was similar between breeds. The seasonal effect of total solids and protein found in our study was in agreement with the literature published by Kala and Prakash (1990) for Indian goats and Mohamed et al. (2007) for Sudanese Nubian. However, Zahraddeen et al. (2007) found no significant effect between dry and wet seasons for indigenous goats in Nigeria. The significant interaction between breed and season suggests that protein concentration may decrease during the cold dry season with a higher level in the rainy season. Litter size had no effect on the composition of milk and this finding is in accordance with the report of Carnicella et al. (2008) in Maltese goats. In contrast, Ćinkulov et al. (2006) reported that goats with more than one kid at parturition had higher milk, fat, and protein yield than goats with single kids in Italy.

\section{Conclusion}

The study has shown that the crossbred goats had better daily milk yield throughout the experiment, with $103 \%$ over the native SG. It indicated also that $1 / 2 \mathrm{AN}$ surpassed the native Sahelian goats in term of concentration of major milk components with an increase of 1.57 and 0.24 for butterfat and protein contents, respectively. The chemical composition of milk varied significantly during seasons and with breeds. It is therefore suggested that a large improvement in the goat milk yield and composition of the local breeds can be made through improved management and crossbreeding with high potential Anglo-Nubian buck to improve the economic value of the local goats. 
Acknowledgments The authors are grateful to the Ministry of Agriculture of Czech Republic, through the Institute of Tropics and Subtropics/CULS Prague for funding Anglo-Nubian bucks, stable reconstruction, and providing equipments for laboratory. Special thanks are due to the staff of the Small Ruminant Research ProgramCRRA/Kayes for technical support, particularly to Seriba Tera, IPRIFRA, for his diligent and responsible data collection.

\section{References}

Berhane, G. and Eik, L.O., 2006. Effect of vetch (Vicia sativa) hay supplementation on performance of Begait and Abergelle goats in northern Ethiopia. Small Ruminant Research, 64, 225-232.

Bonfoh, B., 2005. Dairy policy Projects of Mali: scientific and technical analysis, Annual report, Mali, 52.

Carnicella, D., Dario, M., Caribe Ayres, M.C., Laudadio, V. and Dario, C., 2008. The effect of diet, parity, year and number of kids on milk yield and milk composition in Maltese goat. Small Ruminant Research, 77, 71-74.

Ćinkulov, M., Trivunović, S., Krajinović, M., Popović-Vranješ, A., Pihler, I. and Porcu, K., 2006. Phenotypic and genetic parameters of milk traits of German fawn goats in Serbia. 57th Annual Meeting of the European Association for Animal Production, $51-51$.

Cissé, M., Ly, I., Nianogo, A. J., Sané, I., Sawadogo, J. G., N'diaye, M., Awad, C. and Fall, Y., 2002. Grazing behavior and milk yield of Senegalese Sahel goat. Small Ruminant Research, 43, 85-95.

Cooper, R.A. 2001. Comparison between indigenous and crossbred (Saanen x Indigenous) goats for milk production in Malawi. Proceedings of the 5th International Sheep Veterinary Conference, University of Stellenbosch, South Africa, 21-25.

Delgado-Pertíñez, M., Guzmán-Guerrero, J.L., Caravaca, F.P. Castel, J.M. Ruiz, F.A. González-Redond, P. and Alcalde, M.J., 2009. Effect of artificial vs. natural rearing on milk yield, kid growth and cost in Payoya autochthonous dairy goats. Small Ruminant Research, 84, 108-115.

DNA, 2007. National Department of Agriculture of Mali. Yearly Report.

DNPIA, 2008. Direction Nationale des Productions et Industries Animales, Mali, Rapport annuel

DNS, 1999. Annual statistics of imports of food products in Mali. National Department of Statistics; Bko/Mali.

El-Hassan El-Abid, K. and Abu Nikhaila, A.M.A., 2010. A Study on some son-genetic factors and their impact on milk yield and lactation length of Sudanese Nubian Goats. Australian Journal of Basic and Applied Sciences, 4, 735-739.

Kala, S.N. and Prakash, B., 1990. Genetic and phenotypic parameters of milk yield and milk composition in two Indian goat breeds. Small Ruminant Research, 3, 475-484

Kouniba, A., Berrada, M. and El Marakchi., 2007. Etude comparative de la composition chimique du lait de chèvre de la race locale Marocaine et la race Alpine et évaluation de leur aptitude fromagère. Revue de Médecine Vétérinaire, 158,152-160.

Macciotta, P.P.N., Fresi P., Usai G. and Cappio-Borlino A., 2005. Lactation curves of Sarda breed goats estimated with test day models. Journal of Dairy Research, 72, 470-475.

Malau-Aduli, B.S., Eduvie, L. O. and Lakpini, C. A. M., 2003. Variations in live weight gains, milk yield and composition of Red
Sokoto goats fed crop-residue-based supplements in the sub humid zone of Nigeria. Livestock Production Science, 83, 63-71.

Mioč, B., Prpić, Z., Vnučec, I., Barać, Z., Sušić, V., Samaržija, D. and Pavić, V., 2008. Factors affecting goat milk yield and composition. Mljekarstvo, 4, 305-313.

Missohou, A., Diouf, L., Sow, R. S. and Wollny, C. B. A., 2005. Goat milk production and processing in the Niayes in Senegal. South Africa Journal of Animal Science, 34, 151-154.

Mohamed S.A., Suleiman A.H., Mohamed M.E. and Siddig F.S.E., 2007. A study on the milk yield and compositional characteristics in the Sudanese Nubian under farm conditions. Journal of Animal and Veterinary Advances, 3, 328-334.

Montaldo, H., Juárez A., Berruecos J.M. and Sánchez. F., 1995. Performance of local goats and their backcrosses with several breeds in Mexico. Small Ruminant Research, 16, 97-105.

Morgan, F., Massouras, T., Barbosa, M., Roseiro, L., Ravasco, F., Kandarakis I., Bonnin, V., Fistakoris, M., Anifantakis, E., Jaubert, G. and Raynal-Ljutovac, K., 2003. Characteristics of goat milk collected from small and medium enterprises in Greece, Portugal and France. Small Ruminant Research, 47, 39-49.

Mumba, P.P., Banda, J.W., Nyoni, C.C., Kaliwo, A.E. and Msowoya, S.B.S., 2003. Milk yields, physico-chemical properties and composition of milk from indigenous Malawi goats and their Saanen half-breds. International Journal of Consumer Studies, 27, 185189.

Nantoumé, H., Kouriba, A.. Diarra, C.H.T et Coulibaly, D., 2011. Amélioration de la productivité des petits ruminants : Moyen de diversification des revenus et de lutte contre l'insécurité alimentaire. Livestock Research for Rural Development 23 (5).. http:// www.lrrd.org/lrrd23/5/nant23110.htm.

Nantoumé, H., Ballo A., Traoré, D. et Diarra, C.H.T., 2005. Mise au point des techniques de production de lait de viande et de laine des petits ruminants. Rapport final PR2, $11^{\mathrm{e}}$ session du Comité de Programme de l'Institut d'Economie Rurale, 31-31.

Nianogo, A. J. and Ilboudo, P.C., 1992. Effect of energy level on milk production by Mossi ewes and Sahelian does in Small Ruminant Research and Development in Africa, ILRI, 7-11.

Prasad, H. and Sengar, O.P.S., 2002. Milk yield and composition of the Barbari goat breed and its crosses with Jamunapari, Beetal and Black Bengál. Technical note, Small Ruminant Research 45, 7983

Salem, S. A., El-Agamy, E. I. and Yousseff, A. M., 2004. Effect of crossbreeding between two Egyptian goat breeds on physicochemical, technological and nutritional characteristics of goat milk. South African Journal of Animal Science, 34, 158-161.

Sangaré, M. and Pandey, V. S., 2000. Food intake, milk production and growth of kids of local, multipurpose goats grazing on dry season natural Sahelian rangeland in Mali. Animal Science, 71, 165-173.

Sanogo, S., Mohamed Shaker, M. and Nantoume, H., 2010. Growth performance and milk yield of crossbred Sahelian goats in the semi-arid zone of Mali. Tropentag, 400-400.

SAS, 2002. User's Guide: Statistics. Version 9, (SAS, Institute Inc., Cary, NC).

Stephen P.A. I., Jennie H., Fuen N.C., Anja S., Max S., Roberta B. and Guan K. T., 2004. Comparison of the milk quality of the South African Boer and Australian Rangeland goats Small Ruminant Research. 53, 181-184.

Zahraddeen, D., Butswat, I. S. R. and, Mbap, S. T., 2007. Evaluation of some factors affecting milk composition of indigenous goats in Nigeria. Livestock Research for Rural Development, 19, 11, 166. 